\title{
Study on Managerial Functions of Public Extension Service Providers in Andhra Pradesh, India
}

\author{
S. Naveen Kumar ${ }^{1 *}$, P. Gidda Reddy $^{2}$ and R. Ratnakar ${ }^{3}$ \\ ${ }^{1}$ District Agricultural Advisory \& Transfer of Technology \\ Centre (DAATTC), PJTSAU, Nizamabad, Telangana, India \\ ${ }^{2}$ ANGRAU, Hyderabad, Telangana, India \\ ${ }^{3}$ EEI, ANGRAU, Hyderabad, Telangana, India
}

*Corresponding author

\section{A B S T R A C T}

\section{Keywords \\ Pluralism, \\ Extension Service \\ Providers (ESP), \\ Public, Private and \\ NGOs and \\ Managerial \\ Functions}

\section{Article Info}

Accepted:

22 June 2020

Available Online:

10 July 2020

\section{Introduction}

The emerging trends in the agriculture sector with the rapidly changing government new policies and diversified consumers demands in the market are more significantly influencing on competencies of extension service providers and their sustenance. Under the new economic compulsions and assertive market pulls, the sector is likely to differentiate itself into two prominent segments: one, a small segment moving rapidly towards commercialization of global standards, and another, a larger segment moving slowly towards a kind of dual-goal farming, combining food security with cash farming. Hence in terms of upgrading of managerial skills of public agricultural extension service providers would pave a way to do things most desired way as expected by the governments as well as the society. The public agricultural extension providers should 
therefore be reoriented both to the changes that have occurred in the past, and to the possible demands of the future. Hansra and Singh (2000) suggested reorientation of few functional aspects of extension service providers as follows:

(i) Planning -By involving people in planning and execution of extension programmes, the grass root problems/needs of the people can be identified, It helps to reduce the knowledge gap and increase self reliance of the people. The response to extension programmes can also be increased with participation of the farmers.

(ii) Training -It is necessary to expose extension personnel engaged in training institutes to the modern training methodologies, electronic media, AudioVisual aids, demonstration materials etc. This would increase their credibility in the process of technology transfer.

(iii) Infrastructure facilities-More funds should be allocated to the extension programmes so that as and when the new technique is developed, it can reach the farmers within no time. Efforts are needed to increase the mobility of extension workers by providing adequate transport facilities. They should be provided with more infrastructure facilities, essential teaching and communication equipment etc. A continuous policy funding support from the respective agencies can increase the efficiency of the extension programme.

(iv) Feedback -The farmer problems must be communicated to research scientists more effectively and practical solutions obtained. The effective feed-back from the field must be used by the research and extension personnel in planning, developing and implementing different agricultural extension programmes.
Alex and Byerlee (2002) stated that public sector involvement in the delivery of extension services has diminished, but central governments in low-and middle-income as well as some higher-income countries continue to fund extension-related services, albeit more often delivered by private sector entities. There is increasing concern for both agricultural development and broad-based, other than agriculture entrepreneurial development in rural areas. Extension systems are being called upon to address a number of broad based problems like: food security, clean environment, food quality and related issues, soil equity and sustainable agriculture. Rivera and Alex (2002) opined that capacity building at all levels is critical, and funding for capacity building and institutional strengthening is a sine qua non for near term and future development. But training, like everything else, must have clear objectives related to programme achievement, and it must become more hands-on, involving participants in every aspect of the training. This requires programme development that begins with assessment of employee or farmer needs, not merely training for training's sake. Nanda et al., (2005) expressed that extensionists should have a continuous access to new knowledge and its applications. Training programmes for extensionists need to be devised taking into account the individual extensionists, his extension agency and the system as a whole. If not, the quality of the knowledge with in the extension system will become outdated and be reduced in value.

\section{Materials and Methods}

\section{General Objective}

To study the public, private, and NGOs as agricultural extension service providers in Andhra Pradesh. 


\section{Specific Objective}

To analyze the functional aspects of Public Extension Service Providers

Exploratory and descriptive research design, sampling procedure was adopted for conducting the study (Naveen Kumar et al 2018). There are three regions in Andhra Pradesh namely: Telangana, Rayalaseema and Coastal Andhra. These three regions are considered to represent the entire state of Andhra Pradesh. Those selected districts were: Mahabubnagar from Telangana region, Anantapur from Rayalaseema region and Prakasam from Coastal Andhra region. All the middle level public extension service providers (DAATTC Scientists, ADA's, ADH's, AO's, HO's and KVK scientists) who have been working in the selected four villages were selected purposively. In each district, 15 extension functionaries were selected, thus making a total of 45 as a sample from all three districts.

\section{Functional aspects}

Functional aspects are defined as those to bring together expertise in a scientific way and to create positive attitudes that motivate extension functionaries to achieve organizational goals effectively in a feasible way.

Eleven functional aspects of extension service providers were; planning, organizing, professionalism, decision making, leadership, training, conflict management, human resource development, performance appraisal, feedback and rewards \& awards. Responses of all the functions were taken on three point continuum i.e. Frequently (F), Occasionally $(\mathrm{O})$ and Never (N). Frequency and percentages were calculated. Scoring procedure adopted was 3 for frequently, 2 for occasionally and 1 for never. Average score of each functional aspect of extension service provider was calculated. And class interval method was adopted to distribute respondents.

\section{Results and Discussion}

The results (Table. 1) revealed that majority of the respondents of public extension service providers were found in the high category in all functional aspects viz; planning (97.8\%), organizing $(95.6 \%$,) professionalism $(91.1 \%)$, decision making $(91.1 \%)$, training $(88.9 \%)$, feed back (88.8\%), leadership (77.8\%), human resource development (66.7\%), performance appraisal $(66.7 \%)$ rewards and awards (62.2\%) and conflict management $(42.2 \%)$. It could be noted from the results (table 1) that, maximum number of the respondents of public extension service providers were distributed in high category in all functional aspects namely; planning, organizing, professionalism, decision making, leadership, training, conflict management, human resource development, performance appraisal, feedback and rewards \& awards. This could be due to the effective managerial system in place in public extension service providers. The performance in functional aspects could be still improved with rigorous individual appraisals.

Planning became as strong aspect of the public extension service providers since decades they were involved in Kharif, Rabi and contingency plans to felicitate agricultural development in the state. Organizing groups and their activities to be performed by group members, delegating responsibilities and establishing relationships for the purpose of enabling employees/ extension officials to discharge their roles most effectively in realizing the set objectives also predominantly occupied in high position in public system. While delivering their services in a professional manner and under the guidance of superiors immediate decision making 
abilities also prominently noticed in public extension service providers.

Higher authorities are playing important key role in directing, influencing and controlling ground level extension workers in pursuit of desired and targeted goals. To achieve these goals and reach objectives different training institutions were utilized a systematic and organized procedure by which extension personnel acquire technical knowledge and upscale their skills for a definite and given purpose. Besides this technological and scientific applications are rigorously utilized in the process of achieving their targets with the help of gadgets.

Table.1 Distribution of Public Extension Service Providers (ESP) based on the functional aspects

\begin{tabular}{|c|c|c|c|c|c|}
\hline \multirow[t]{2}{*}{ S.No. } & \multirow[t]{2}{*}{ Functional Aspects } & \multirow[t]{2}{*}{ Category } & \multirow[t]{2}{*}{ Range } & \multicolumn{2}{|c|}{ Public ESP $(n=45)$} \\
\hline & & & & $\mathbf{F}$ & $\%$ \\
\hline \multirow[t]{3}{*}{1} & \multirow[t]{3}{*}{ Planning } & Low & $6-9$ & - & - \\
\hline & & Medium & $10-13$ & 1 & 2.2 \\
\hline & & High & $14-18$ & 44 & 97.8 \\
\hline \multirow[t]{3}{*}{2} & \multirow{3}{*}{ Organizing } & Low & $5-7$ & - & - \\
\hline & & Medium & $8-11$ & 2 & 4.4 \\
\hline & & High & $12-15$ & 43 & 95.6 \\
\hline \multirow[t]{3}{*}{3} & \multirow[t]{3}{*}{ Professionalism } & Low & $7-11$ & - & - \\
\hline & & Medium & $12-16$ & 4 & 8.9 \\
\hline & & High & $17-21$ & 41 & 91.1 \\
\hline \multirow[t]{3}{*}{4} & \multirow[t]{3}{*}{ Decision making } & Low & $6-9$ & - & - \\
\hline & & Medium & $10-13$ & 4 & 4.9 \\
\hline & & High & $14-18$ & 41 & 91.1 \\
\hline \multirow[t]{3}{*}{5} & \multirow[t]{3}{*}{ Leadership } & Low & $7-11$ & 1 & 2.2 \\
\hline & & Medium & $12-16$ & 9 & 20 \\
\hline & & High & $17-21$ & 35 & 77.8 \\
\hline \multirow[t]{3}{*}{6} & \multirow[t]{3}{*}{ Training } & Low & $7-11$ & 1 & 2.2 \\
\hline & & Medium & $12-16$ & 4 & 8.9 \\
\hline & & High & $17-21$ & 40 & 88.9 \\
\hline \multirow[t]{3}{*}{7} & \multirow[t]{3}{*}{ Conflict Management } & Low & $5-7$ & 9 & 20 \\
\hline & & Medium & $8-11$ & 17 & 37.8 \\
\hline & & High & $12-15$ & 19 & 42.2 \\
\hline \multirow[t]{3}{*}{8} & \multirow{3}{*}{$\begin{array}{l}\text { Human Resource Development } \\
\text { (HRD) }\end{array}$} & Low & $9-14$ & 2 & 4.4 \\
\hline & & Medium & $15-20$ & 13 & 28.9 \\
\hline & & High & $21-27$ & 30 & 66.7 \\
\hline \multirow[t]{3}{*}{9} & \multirow[t]{3}{*}{ Performance Appraisal } & Low & $5-7$ & 2 & 4.4 \\
\hline & & Medium & $8-11$ & 13 & 28.9 \\
\hline & & High & $12-15$ & 30 & 66.7 \\
\hline \multirow[t]{3}{*}{10} & \multirow[t]{3}{*}{ Feedback } & Low & $6-9$ & - & - \\
\hline & & Medium & $10-13$ & 5 & 11.1 \\
\hline & & High & $14-18$ & 40 & 88.8 \\
\hline \multirow[t]{3}{*}{11} & \multirow[t]{3}{*}{ Rewards \& Awards } & Low & $6-9$ & 1 & 2.2 \\
\hline & & Medium & $10-13$ & 16 & 35.6 \\
\hline & & High & 14-18 & 28 & 62.2 \\
\hline
\end{tabular}


If any conflicts arise in the process of attaining the goals, organizational heads immediately recognizes the importance of positive conflicts to enhance the efficiency of the extension service providers. Capacity building programmes also helped the extension service providers to improve their knowledge, skills, attitude and all personality aspects so as to cope up with the changed scenario. Frequent performance appraisal procedures also implemented and help in evaluating the performance and qualifications of extension personnel in terms of achievements on the job for which they were employed. Effective feedback mechanism enabled the extension service providers in receiving some significant responses from the clientele to adjustments of future activities in the light of achieving in a given goal. Apart from all timely and suitable recognition procedures either physical or hygienic incentives have been giving on the day of state and central occasions and national importance days motivated extension functionaries to work more effectively, efficiently and timely.

In conclusion the spite of having several hurdles while delivering public extension services, the extension workers are striving hard to achieve their objectives and to reach their goals. This made, still public extension service system more reliable, professional and amicable to majority of the farmers.

\section{References}

Alex, G., Nielson, D. and Byerlee D. (2002). Agricultural Extension Investments; Future Options for Rural Development. Washington DC: the World Bank.

Hansra, B. S. and Singh, M. (1999) Agricultural extension beyond 2000, JEE, Vol.10 No.3.

Nanda, R., Baru, P. and Gupta, V. (2005). New reforms in agricultural extension system, Agricultural extension review, pp.28-30, September-October.

Naveen Kumar. S., P. Gidda Reddy and Ratnakar. R. (2018). Perception of Farmers on Agricultural Extension Service Providers (Public, Private and NGO Extension Service Providers) in Andhra Pradesh, India. Int.J.Curr.Microbiol.App.Sci. $\quad 7(03)$ : 3772-3779.

Rivera, W.M. and Alex, G. (2002). Extension reform for rural development; case studies of international initiatives, Washington DC: World Bank. (www.worldbank.org/extension).

\section{How to cite this article:}

Naveen Kumar, S., P. Gidda Reddy and Ratnakar, R. 2020. Study on Managerial Functions of Public Extension Service Providers in Andhra Pradesh. Int.J.Curr.Microbiol.App.Sci. 9(07): 3320-3324. doi: https://doi.org/10.20546/ijcmas.2020.907.388 